\title{
What kind of landscape management can counteract the extinction of experience?
}

\author{
Agathe COLLEONY ${ }^{\mathrm{a}} *$ \\ (agathe.colleony@gmail.com) \\ Anne-Caroline PREVOT ${ }^{\mathrm{a}}$ \\ (acpj@mnhn.fr) \\ Michel SAINT JALME ${ }^{\mathrm{a}}$ \\ (michel.saint-jalme@mnhn.fr) \\ Susan CLAYTON ${ }^{\mathrm{b}}$ \\ (sclayton@wooster.edu) \\ ${ }^{a}$ Centre d'Ecologie et des Sciences de la Conservation (CESCO UMR7204), Sorbonne \\ Universités, MNHN, CNRS, UPMC, CP51, 57 rue Cuvier, 75005 Paris, France \\ ${ }^{b}$ Department of Psychology, College of Wooster, 1189 Beall Avenue, Wooster, OH 44691 , \\ United States \\ *Corresponding author: Agathe Colléony \\ Tel : +331407935 57 \\ Email address: agathe.colleony@gmail.com
}

This manuscript has been published in Landscape and Urban Planning, and should be cited as follow:

Colléony A., Prévot A-C., Saint-Jalme M. \& Clayton S. (2017) What kind of landscape management can counteract the extinction of experience? Landscape and Urban Planning. 159: 23-31. 


\begin{abstract}
Much research has explored the effects of being in natural areas on human health, well-being and environmental concern. However, the combined effects of urbanization, biodiversity loss and the Western way of life reduce the opportunities to experience nature. Landscape management could play a prominent role in providing opportunities and motivation for people to be in nature. It is important, therefore, to understand which kinds of nature people mostly prefer and use. Based on complementary questionnaire surveys obtained from 4639 French adults, we studied the habits of nature uses, in relation to personal previous experiences and nature connectedness. We explored the type and frequency of natural areas people visit most often, the place where they grew up, and the extent to which they feel interdependent with the natural environment. In an innovative process, we assessed the extent to which respondents mentioned a personal place (e.g., my garden), a specific non-personal place (e.g. a particular forest) or remained general (e.g. forests). Among a wide range of cited natural areas, five types predominated, consistently for all samples surveyed. Interestingly, connectedness with nature was negatively related to mentions of place specificity, but positively related to frequency of visits of natural areas. These results clarify the relationship between past and present experiences of nature and sense of connectedness to nature. They can also guide future landscape management processes, in order to better coordinate the provision and the desirability of natural spaces and promote both sustainable landscapes and reconnection of people to nature.
\end{abstract}

Keywords: natural place, experience of nature, place attachment, connectedness to nature, forest, urban park

\title{
Research Highlights
}

- A large diversity of natural places was visited, but five types predominated.

- Places that are not valued by ecologists are considered as natural by people.

- Connectedness to nature was negatively linked to specification of environments.

- Results suggest important directions for increasing opportunity and orientation. 


\section{Introduction}

One aspect of the biodiversity crisis is the "extinction of [nature] experience" (Miller, 2005; Pyle, 1978). In a recent review, Soga and Gaston (2016) proposed that urbanization and a western way of life induce both a loss of opportunities and a loss of orientation to go to natural places and experience nature; the disconnection from nature induces in turn health and well-being changes, as well as emotional, attitudinal and behavioral changes, which then affect the importance assigned to nature. Based on this feedback loop, Western modern societies face a vicious cycle regarding nature conservation.

Stopping this deleterious phenomenon requires increasing the opportunities to be in contact with nature, together with the orientation and motivation to visit natural places. First, as reviewed by Soga and Gaston (2016), people who live farther from natural areas interact less frequently with nature (Soga et al., 2015). Providing green infrastructures close to where people live or work could allow people to develop emotional attachment to the outdoors, and motivate them to further experience nature (Bixler, Floyd, \& Hammitt, 2002). However, in many cases, simply increasing opportunities to be in contact with nature is not sufficient to encourage people to seek out contact with nature. For instance, in a survey comparing park users with non-users, Lin et al. (2014) found that non-park users comprised almost $40 \%$ of the surveyed population, and that this significant group of people might not use local green areas even if those areas are available close to their homes. They also found that the willingness to visit parks and experience nature was driven more by nature orientation than by opportunity. Enhancing willingness and orientations to use natural places should therefore be achieved in tandem with increasing opportunities (Soga \& Gaston, 2016).

Increasing opportunities to visit natural places can be achieved through landscape planning, in which natural and green spaces are implemented in such conditions that they can be visited and used (Miller \& Hobbs, 2002; Soga et al., 2015). This planning should be based on accurate scientific studies, for instance related to the benefits of such places for visitors. And indeed, numerous studies have been already published about benefits of natural environments for people (Bratman, Hamilton, \& Daily, 2012; Sandifer, SuttonGrier, \& Ward, 2015). However, in most of them, the studied natural places are preTo cite this manuscript: Colléony A., Prévot A-C., Saint-Jalme M. \& Clayton S. (2017) What kind of landscape management can counteract the extinction of experience? Landscape and Urban Planning. 159: 23-31. 
defined by the researchers: many authors focus on cities and consider urban greenspaces as the natural areas compared to urban settings (Bratman, Hamilton, Hahn, Daily, \& Gross, 2015; Soga et al., 2015). Mitchell and Popham (2008) extended their definition of green spaces to parks, open spaces and agricultural areas and excluded private gardens; Han (2007) presented slides of different ecological biomes to the respondents. Yet, an accurate landscape planning would benefit from assessing which categories of landscapes people actually define as "natural spaces", as well as which ones they visit and to what extent. This knowledge could help design and plan natural landscapes that would increase real opportunities for people to go to nature.

Beyond providing opportunities to visit natural areas, landscape planning could also help increase individuals' inclination to visit natural places, by taking into account the different motivations to visit these places. According to Kaplan and Kaplan (1989), the psychological, social and physiological benefits natural settings can provide could be the drivers of humans' preference for natural environments. Many studies have explored these human-nature relationships, and explored the respective roles of individual knowledge, attitude, or representation of nature (Buijs et al., 2012; Clayton, Fraser, \& Saunders, 2009; Nisbet, Zelenski, \& Murphy, 2009; Schultz, 2000). They showed in particular the importance of experiencing nature during childhood. Indeed, limited contacts with nature during childhood are suspected to decrease the prominence of environmental concern in adults (Hinds \& Sparks, 2008; Wells \& Lekies, 2006). And children nowadays visit nature less often than do adults (Soga and Gaston 2016), resulting in lower curiosity and knowledge about the natural world (Lindemann-Matthies, 2006). Research suggests that an environmental identity, or stable sense of oneself as interdependent with the natural world, develops primarily during childhood (Chawla, 1988). Thus, when children do not have the opportunity to spend time in nature, the result may be a weaker environmental identity when becoming adults. Environmental identity is reflected in a sense of connection to nature, which promotes attention to and concern about the natural environment (Clayton, 2012; Schultz, 2001). Experiencing nature through visits to natural places during adulthood allows people to continue building their relationship with nature through memories of childhood events in natural environments, and thus reinforce their relationship with nature. As such, we could imagine that a prior strong affective To cite this manuscript: Colléony A., Prévot A-C., Saint-Jalme M. \& Clayton S. (2017) What kind of landscape management can counteract the extinction of experience? Landscape and Urban Planning. 159: 23-31. 
relationship with nature may lead people to visit natural places more often during adulthood.

For a given individual, the willingness to visit natural places could be a general tendency, not tied to specific areas. However, it could also lead people to visit some specific natural places, in association with the development of an attachment to these particular places. The drivers and components of place attachment have largely been explored in social psychology (Anton \& Lawrence, 2014; Gosling \& Williams, 2010), but little research effort has focused on the role of attachment to particular natural places in an individual's relationship with nature more generally.

Despite the large amount of research on relationships to nature, little research effort seems to have focused on real behaviors, to ask which kind of natural places people do visit and in what frequency together with their previous experiences of nature and nature connectedness. Our study aimed therefore at characterizing the experience of nature of more than 4000 French adult people. To do so, as Soga and Gaston (2016) did, we first explored the frequency of visit to natural areas. However, we explored also two new specific assessments: first, we asked people to identify the "natural places" they visit; then, from their answers, we built an indicator of "place specificity", which approaches how a given individual appears to be attached to specific places. We studied how these three proxies of experience of nature are related to the level of nature people have been in contact with during childhood, as well as to their connectedness with nature.

\section{Methods}

\subsection{Survey instrument}

For the aim of this study, we pooled data from five different questionnaire surveys (respectively named "student", "wow", “zoo", "web" and "adopter"), so we had 4639 questionnaires in total. The number of questionnaires, targeted audience, aims of the original surveys, administration method and period of data collection of each questionnaire survey are detailed in Table 1. The targeted audience was French-speaking adult communities. The five questionnaire surveys were part of different research projects, all of which aimed at a better understanding of human-nature relationships (e.g. virtual or particular experiences of nature). The data were pooled to obtain a larger sample size, To cite this manuscript: Colléony A., Prévot A-C., Saint-Jalme M. \& Clayton S. (2017) What kind of landscape management can counteract the extinction of experience? Landscape and Urban Planning. 159: 23-31. 
and explore whether there was an overall pattern in the results or if it differed depending on the context.

In all the surveys, we explored people's connectedness with nature, frequency of visits to natural places, natural places they primarily visit, age, gender, and rural setting during childhood; all these questions were written with the exact same wording in the five surveys.

\subsection{Questions and associated computed variables}

\subsubsection{Connectedness with nature}

We used an adapted version of the Inclusion of Other in the Self (IOS) scale (Aron, Aron, \& Smollan, 1992) to measure individuals' beliefs of how interconnected people feel with the natural world, via a series of five pairs of overlapping circles labeled nature and self (Schultz, 2001): data were coded from 1 for the less overlapping pair of circles, to 5 for the completely overlapping circles.

\subsubsection{Frequency of visits of natural places}

We used a 5-point scale to measure the frequency of visits to natural places, ranging from 0-“never", 1 -“few times a year", 2-“once a month", 3-“once a week", up to 4“everyday".

\subsubsection{Name and "place specificity" of the natural places they visit mostly}

The respondents then answered the following open-ended question: "To which natural place do you mostly go?" Respondents were free to give several natural places.

Based on respondents' free answers, we computed a synthetic index of so-called "place specificity", in 3 levels: 0 for general, unspecified places (e.g. "forest", "countryside", "parks"), 1 for named places (e.g. "Paris Zoo", "Vincennes park", "Britany"), 2 for

personalized or owned places ("my garden", "my parents' garden", “ours: park and forest"). Our goal was to get at the extent to which people were committed to a specific place. We assigned one value (from 0 to 2) to each cited place. Several values of this index could be present for a single respondent, depending on the number of cited natural places.

To cite this manuscript: Colléony A., Prévot A-C., Saint-Jalme M. \& Clayton S. (2017) What kind of landscape management can counteract the extinction of experience? Landscape and Urban Planning. 159: 23-31. 
Table 1: Description of the survey instrument, with number of questionnaires, targeted audience, aim of the survey, administration method and period of data collection for each of the five pooled surveys.

\begin{tabular}{|c|c|c|c|c|c|}
\hline Group & $\begin{array}{c}\text { Number of } \\
\text { questionnaires }\end{array}$ & Targeted audience & Aim of the survey & $\begin{array}{l}\text { Administration } \\
\text { method }\end{array}$ & $\begin{array}{l}\text { Period of } \\
\text { data } \\
\text { collection }\end{array}$ \\
\hline $\begin{array}{c}\text { (1) } \\
\text { student }\end{array}$ & 1126 & $\begin{array}{l}\text { French university } \\
\text { students (biology, } \\
\text { ecology, } \\
\text { mathematics and } \\
\text { politics }) \text { mostly } \\
18-25 \text { years old } \\
(86 \%) \text { and women } \\
(47 \%)\end{array}$ & $\begin{array}{l}\text { Explore student's } \\
\text { environmental } \\
\text { identity }\end{array}$ & $\begin{array}{l}\text { Printed materials - } \\
\text { in classes }\end{array}$ & $\begin{array}{c}\text { September } \\
2013- \\
\text { March } 2014\end{array}$ \\
\hline $\begin{array}{l}(2) \\
\text { wow }\end{array}$ & 1172 & $\begin{array}{c}\text { French adults } \\
\text { players of an online } \\
\text { role-playing game } \\
\text { (World of Warcraft) } \\
\text { - mostly } 18-25 \text { years } \\
\text { old }(61 \%) \text { and men } \\
(84 \%) \\
\end{array}$ & $\begin{array}{l}\text { Explore gamer's } \\
\text { virtual relationship } \\
\text { with nature }\end{array}$ & $\begin{array}{l}\text { Internet-based } \\
\text { survey }\end{array}$ & $\begin{array}{c}\text { June - } \\
\text { August } 2014\end{array}$ \\
\hline $\begin{array}{l}(3) \\
\text { zoo }\end{array}$ & 446 & $\begin{array}{c}\text { French speaking } \\
\text { visitors of three zoos } \\
\text { in France (two urban } \\
\text { in Paris, one rural in } \\
\text { the center of France) } \\
\text { - mostly } 36-40 \text { years } \\
\text { old }(34 \%) \text { and } \\
\text { women }(54 \%)\end{array}$ & $\begin{array}{c}\text { Explore the } \\
\text { visitors' perception } \\
\text { of the zoo and } \\
\text { biodiversity } \\
\text { conservation, and } \\
\text { visitors' } \\
\text { relationship with } \\
\text { nature } \\
\end{array}$ & $\begin{array}{l}\text { Printed materials } \\
\text { - in the zoos }\end{array}$ & $\begin{array}{c}\text { July - } \\
\text { August } 2014\end{array}$ \\
\hline $\begin{array}{l}(4) \\
\text { web }\end{array}$ & 342 & $\begin{array}{l}\text { French speaking } \\
\text { people receiving a } \\
\text { link by email to } \\
\text { complete this survey } \\
\text { or following the link } \\
\text { posted on the } \\
\text { Facebook page of a } \\
\text { zoo - mostly } 26-40 \\
\text { years old }(49 \%) \text { and } \\
\text { women }(65 \%)\end{array}$ & $\begin{array}{l}\text { Explore people's } \\
\text { perception of the } \\
\text { zoo, biodiversity } \\
\text { conservation, and } \\
\text { their relationship } \\
\text { with nature; } \\
\text { Compare with zoo } \\
\text { visitors }\end{array}$ & $\begin{array}{l}\text { Internet-based } \\
\text { survey }\end{array}$ & $\begin{array}{l}\text { End of April } \\
2015\end{array}$ \\
\hline $\begin{array}{l}(5) \\
\text { adopter }\end{array}$ & 1553 & $\begin{array}{l}\text { French speaking } \\
\text { people who } \\
\text { participated in the } \\
\text { "animal adoption } \\
\text { program" of } \\
\text { Paris'zoo - mostly } \\
41-60 \text { years old } \\
(38 \%) \text { and women } \\
(71 \%)\end{array}$ & $\begin{array}{l}\text { Explore people's } \\
\text { motivations to } \\
\text { adopt an animal } \\
\text { through the zoo and } \\
\text { their relationship } \\
\text { with nature }\end{array}$ & $\begin{array}{l}\text { Internet-based } \\
\text { survey }\end{array}$ & $\begin{array}{l}\text { April - May } \\
2015\end{array}$ \\
\hline
\end{tabular}

To cite this manuscript: Colléony A., Prévot A-C., Saint-Jalme M. \& Clayton S. (2017) What kind of landscape management can counteract the extinction of experience? Landscape and Urban Planning. 159: 23-31. 


\subsubsection{Rural setting during childhood}

We recorded whether participants spent their childhood in a rural or more urban setting using a 5-point scale, ranging from 1-"large city”, 2-“medium city”, 3-“small city”, 4"village" to 5-"hamlet".

\subsubsection{Age}

Depending on the surveys, age was assessed either through the year of birth or by category. For homogenization, we summarized all these data in five categories: 1 for people under 18, 2 for 18 to 25,3 for 26-40, 4 for 41-60 and 5 for people above 61 years old.

\subsection{Data analyses}

All the analyses were performed using R 3.0.2 (R Core Team, 2013).

We first examined the raw data of the three proxies of the experiences of nature (i.e. frequency of visit of natural places, names of the most visited places and index of place specificity), and we tested whether the results were consistent between the different surveyed groups using chi-squared tests.

Then, we explored the relations between current experiences of nature and individual characteristics, in the following ways:

\subsubsection{Determinants of the frequency of visit to natural places}

We used a linear regression to explore determinants of the frequency of visit of natural places, with the frequency of visit of natural places (VIS) as the response variable, and rural setting during childhood (RUR), connectedness with nature (INS), age (AGE), gender (SEX) and group (GPE) as the independent variables. The group variable was only included in the model to take into account differences between groups (see results). We also considered interactions between RUR, INS, AGE and SEX. We then applied a stepwise model selection based on Akaike information criterion (AIC) scores to select the best model. Finally, we conducted an type III-anova on the best model we selected (Fox \& Weisberg, 2016). 


\subsubsection{Determinants of visits of the most cited natural places}

We used logistic regressions to explore whether visiting the most cited natural places could be predicted by connectedness with nature (INS), rural setting during childhood (RUR), age (AGE), gender of respondents (SEX) and surveyed group (GPE). We also added the frequency of visits to natural places during adulthood (VIS) among explanatory variables, because we could not exclude the possibility that the identity of the most visited places depend on the frequency individuals with which generally visit natural areas. Interactions between INS, RUR, AGE and SEX were also considered.

We entered the cited natural place (binary data set, showing whether each respondent named this specific place or not) as the response variable, and INS, RUR, VIS, SEX, AGE and GPE as independent variables. We applied this procedure for the two most quoted natural places in the whole data set, i.e. forest and park (see results). We then applied a stepwise model selection based on Akaike information criterion (AIC) scores to select the best model for each natural place (i.e. forest and park). Finally, we conducted a type III anova on the best model we selected (Fox \& Weisberg, 2016).

\subsubsection{Determinants of place specificity}

We modeled determinants of place specificity using ordinal regression model (Haubo, 2015) with place specificity (PSP) as the response variable and rural setting during childhood (RUR), age (AGE), gender (SEX), connectedness with nature (INS), frequency of visits of natural places during adulthood (VIS) and surveyed group (GPE) as independent variables. We also considered interactions between RUR, AGE, SEX, INS and VIS. Because participants were allowed to give several responses, we built for this analysis a separate dataset containing as much replications of each individual's information as the number of natural places he/she mentioned. In other words, if an individual mentioned two natural places, this individual appeared twice in the data set. We thus applied a random effect to the participant variable, to control for multiple responses of natural places per person.

We then conducted a stepwise model selection based on Akaike information criterion (AIC) scores to select the best model. 


\section{Results}

\subsection{Description of the sample set}

For all surveyed groups, age was negatively related to rural setting during childhood (the relationship was similar but not significant for two of the samples, web and zoo groups with low amounts of data), suggesting that older persons were more likely to have grown up in urban places.

Similarly, for all groups, age was positively related to INS, suggesting that older persons were more likely to feel more connected to nature (the relationship was not significant among three of the samples, adopters, wow and zoo), and INS was positively related to rural setting during childhood, suggesting that those who grew up in a more rural place were more likely to feel more connected to nature.

\subsection{Distribution of the three proxies of experience of nature among 4639 French adults}

\subsubsection{Frequency of visit to natural places:}

Frequency of visit to natural places significantly differed between the surveyed groups $(\chi=755.41, \mathrm{df}=16, \mathrm{p}<2.2 \mathrm{e}-16)$. All surveyed groups were consistent in the score 0 ("never", 0 to $4 \%$ of respondents in each survey), as well as in the score 3 ("once a week", 32 to $44 \%$ of respondents). However, there was a large variation between surveyed groups for other frequencies (i.e. 1 - "once a year", 2 - "once a month", and 4 - "every day"; proportion of respondents varied from 11 to $34 \%$ ).

\subsubsection{Quoted natural places}

We analyzed data from 4639 questionnaires, leading to a total of 7761 cited natural places in total, due to multiple answers (up to 8). Crosschecking for identical places led to 678 different natural places. We found that 16 of these natural places were each named by at least 50 persons (i.e. 5912 mentions), and so represented $76.2 \%$ of the total named places (Table 2). More specifically, 54\% of the total mentions (i.e. 4194 mentions) were represented by only five different places: forest, park, countryside, mountain and garden (Table 2). "Woodland" and "forest", as well as "parks" and "urban parks", were not aggregated on purpose, to take into account respondent's specific responses, but these places are very similar and might have been aggregated. Combining To cite this manuscript: Colléony A., Prévot A-C., Saint-Jalme M. \& Clayton S. (2017) What kind of landscape management can counteract the extinction of experience? Landscape and Urban Planning. 159: 23-31. 
these two first categories could lead the "forest" type response increasing up to $40 \%$ mentions. Other places cited by at least 50 persons included sea, woodland, beach, zoo, public garden, fields, Vincennes' wood (i.e. a public natural area located in Paris), sea side, lake, river and urban park (Table 2).

Table 2: List of the most quoted natural places, with respective number of quotes, cumulative numbers of quotes and cumulative percentage of quotes. Natural places are translated from the French quoted places (in italics). "Park » stands for people who quoted "park" without specifying which type of park (other places include "national park" for instance). "Others" stands for all other responses quoted by less than 50 participants.

\begin{tabular}{|l|c|c|c|}
\hline Natural place & \# quotes & $\begin{array}{c}\text { \# cumulative } \\
\text { quotes }\end{array}$ & $\begin{array}{c}\text { \% cumulative } \\
\text { quotes }\end{array}$ \\
\hline Forest (forêt) & 1619 & 1619 & 20.9 \\
\hline Park (parc) & 973 & 2592 & 33.4 \\
\hline Countryside (campagne) & 630 & 3222 & 41.5 \\
\hline Mountain (montagne) & 512 & 3734 & 48.1 \\
\hline Garden (jardin) & 460 & 4194 & 54 \\
\hline Sea (mer) & 415 & 4609 & 59.4 \\
\hline Woodland (bois) & 281 & 4890 & 63 \\
\hline Beach (plage) & 171 & 5061 & 65.2 \\
\hline Zoo (zoo) & 162 & 5223 & 67.3 \\
\hline Public garden (jardin public) & 147 & 5370 & 69.2 \\
\hline Fields (champs) & 132 & 5502 & 70.9 \\
\hline Vincennes'wood (bois de & 114 & 5616 & 72.3 \\
Vincennes) & & & 73.7 \\
\hline Sea side (bord de mer) & 107 & 5723 & 74.8 \\
\hline Lake (lac) & 83 & 5806 & 75.5 \\
\hline River (rivière) & 56 & 5862 & 76.2 \\
\hline Urban park (parc urbain) & 50 & 5912 & 100 \\
\hline Others & 1849 & 7761 & \\
\hline
\end{tabular}

To test whether the results were consistent across the five survey groups, we ranked the most named natural places for each group (see Supporting Information). Forested areas were the most cited areas in each of the five groups. Parks and countryside also ranked within the five first places, while mountains and gardens ranked from the $2^{\text {nd }}$ place (garden, for the "web" group) to the $8^{\text {th }}$ (mountain, for the "web" group). Ranks for the five most cited places did not significantly differ from one group to another $(\chi=8.32$, 
$\mathrm{df}=16, \mathrm{p}=0.94)$. This suggests high consistency in the answers of the five groups of respondents, although they are composed of very different people.

\subsubsection{Place specificity}

Most natural places mentioned (67 to 90\%) in all surveyed groups were general, unspecified places (scored as 0), while the least frequently mentioned (3 to $11 \%$ ) were owned places (scored as 2). However, proportions of each level of place specificity significantly differed between the surveyed groups $\left(\chi^{2}=271.00, \mathrm{df}=8, \mathrm{p}<2.2 \mathrm{e}-16\right)$ : e.g. the "wow" and "student" groups largely differ, with less scores of 0, but more scores of 1 and 2 for the "wow" group, and more places scored as 0 , and less places scored as 1 and 2 for the "student" group. Other group scores vary between the values of those two groups.

In the following analyses, we considered the overall data set for determinants of adult experiences of nature. However, because we found differences between the five groups of respondents for two of the three proxies of experiences of nature, we included the surveyed group as an independent variable, to take such differences into account in the models.

\subsection{Determinants of adult experiences of nature}

\subsubsection{Determinant of the frequency of visit to natural places}

According to the best model from the stepwise model selection (Table 3), rural setting during childhood and connectedness with nature were both strongly and positively associated with frequency of visit of natural places during adulthood (RUR: $F=85.546$, $\mathrm{df}=1, \mathrm{p}<0.001$; INS: $\mathrm{F}=261.013, \mathrm{df}=1, \mathrm{p}<0.001$ ), suggesting that respondents who spent their childhood in a rural place and those who feel more connected to nature are more likely to visit more often natural places than other respondents. As previously found in the descriptive analysis, we found a significant effect of the group variable $(\mathrm{F}=36.325$, $\mathrm{df}=4, \mathrm{p}<0.001$ ). Some interactions were also significant (Table 3), suggesting that the frequency of visits to natural places was relatively lower for older respondents who spent their childhood in a rural setting (negative effect of RUR:AGE; $\mathrm{F}=14.085$, $\mathrm{df}=1$, $\mathrm{p}<0.001$ ), for older respondents who felt more connected to nature (negative effect of INS:AGE; $\mathrm{F}=9.538, \mathrm{df}=1, \mathrm{p}=0.002$ ), and for men who felt more connected to nature To cite this manuscript: Colléony A., Prévot A-C., Saint-Jalme M. \& Clayton S. (2017) What kind of landscape management can counteract the extinction of experience? Landscape and Urban Planning. 159: 23-31. 
(negative effect of INS:SEXm; $\mathrm{F}=6.568, \mathrm{df}=1, \mathrm{p}=0.010$ ), but that this frequency of visits to natural places was higher for men who spent their childhood in a rural setting (positive effect of RUR:SEXm; $\mathrm{F}=5.040, \mathrm{df}=1, \mathrm{p}=0.025$ ).

\subsubsection{Determinants of the two most quoted natural places: forests and parks}

Based on the best model in the logistic regression (see Table), forests were more often mentioned by people having spent their childhood in more rural places (positive effect of RUR; $\mathrm{F}=25.808, \mathrm{df}=1, \mathrm{p}<0.001$ ), being more connected to nature (positive effect of INS; $\mathrm{F}=16.133, \mathrm{df}=1, \mathrm{p}<0.001$ ) and visiting more often natural spaces (positive effect of VIS; $F=13.821, d f=1, p<0.001)$; at the opposite, the older the respondents were, the less they mentioned "forest" (negative effect of $\mathrm{AGE} ; \mathrm{F}=5.956, \mathrm{df}=1, \mathrm{p}<0.05$ ). We also found significant differences between groups $(\mathrm{F}=116.048, \mathrm{df}=4, \mathrm{p}<0.001)$ and between men and women $(\mathrm{F}=9.762, \mathrm{df}=1, \mathrm{p}=0.002)$, with a larger number of "forest" responses for men. We found some significant interactions, suggesting that the propensity of "forest" responses was lower for older respondents who felt more connected to nature (negative effect of INS:AGE; F=4.175, $\mathrm{df}=1, \mathrm{p}=0.041$ ), and for older respondents who spent their childhood in a rural setting (negative effect of RUR:AGE; $F=5.075, \mathrm{df}=1, \mathrm{p}=$ 0.024), but that the propensity of "forest" responses was higher for men who spent their childhood in a rural setting (positive effect of RUR:SEXm; F=8.088, df=1, p = 0.004).

Similarly to "forest", the term "park" was significantly less often mentioned by older people (negative effect of $\mathrm{AGE} ; 46.482, \mathrm{df}=1, \mathrm{p}<0.001$ ). However, based on the best model in the logistic regression (see Table 3), the mention of "park" significantly decreased with rural setting during childhood (negative effect of RUR; $F=41.218, \mathrm{df}=1, \mathrm{p}$ $<0.001$ ), as well as with the connection to nature (negative effect of INS; F=6.086, $\mathrm{df}=1, \mathrm{p}=0.014)$. We found significant differences between groups $(\mathrm{F}=152.137, \mathrm{df}=4, \mathrm{p}<$ $0.001)$ and between men and women $(\mathrm{F}=14.293, \mathrm{df}=1, \mathrm{p}<0.001)$, with a lower number of "park" responses for men. The frequency of visit to natural places did not have any significant effect. Finally, we found some significant interactions, suggesting that the propensity of "park" responses was lower for respondents who visit natural places more often and who spent their childhood in a rural setting (negative effect of RUR:VIS; $\mathrm{F}=21.485, \mathrm{df}=1, \mathrm{p}<0.001$ ) and for men who visit natural places more often (negative 
effect of VIS:SEXm; $\mathrm{F}=4.553, \mathrm{df}=1, \mathrm{p}=0.033$ ), but this propensity of "park" responses was higher for older respondents who spent their childhood in a rural setting (positive effect of RUR:AGE; $\mathrm{F}=24.932$, $\mathrm{df}=1, \mathrm{p}<0.001)$.

Table 3: Stepwise model selections based on Akaike Information Criterion (AIC), for determinants of frequency of visits to natural places, determinants of the two most cited natural places, and determinants of place specificity (VIS: Frequency of visit to natural places; GPE: surveyed group; AGE: age; SEX: gender; RUR: rurality level of place of childhood; INS: connectedness with nature; PSP: place specificity). The selected final models are in bold characters.

\begin{tabular}{|c|c|}
\hline Models & AIC \\
\hline \multicolumn{2}{|l|}{ Determinants of frequency of visit to natural places } \\
\hline VIS GPE + AGE + SEX + RUR + INS & 10988.73 \\
\hline $\begin{array}{l}\text { VIS GPE + AGE + SEX + RUR + INS + AGE:SEX + AGE:RUR + AGE:INS + SEX:RUR + SEX:INS } \\
\text { + RUR:INS }\end{array}$ & 10953.39 \\
\hline $\begin{array}{l}\text { VIS GPE + AGE + RUR + INS + AGE:SEX + AGE:RUR + AGE:INS + SEX:RUR + SEX:INS + } \\
\text { RUR:INS }\end{array}$ & 10951.42 \\
\hline VIS GPE + RUR + INS + AGE:SEX + AGE:RUR + AGE:INS + SEX:RUR + SEX:INS + RUR:INS & 10951.42 \\
\hline VIS GPE + RUR + INS + AGE:SEX + AGE:RUR + AGE:INS + SEX:RUR + SEX:INS & 10949.53 \\
\hline \multicolumn{2}{|l|}{ Determinants of the two most quoted natural places } \\
\hline $\begin{array}{l}\text { 'Forest' GPE + RUR + INS + VIS + AGE + SEX + RUR:INS + RUR:VIS + RUR:AGE + RUR:SEX + } \\
\text { INS:VIS + INS:AGE + INS:SEX + VIS:AGE + VIS:SEX + AGE:SEX }\end{array}$ & 5411.7 \\
\hline 'Forest' GPE + RUR + INS + VIS + AGE + SEX & 5415.3 \\
\hline $\begin{array}{l}\text { 'Forest' GPE + RUR + INS + VIS + AGE + SEX + RUR:SEX + INS:VIS + INS:AGE + INS:SEX + } \\
\text { VIS:AGE + VIS:SEX + AGE:SEX }\end{array}$ & 5407.2 \\
\hline $\begin{array}{l}\text { 'Forest' GPE + RUR + INS + VIS + AGE + SEX + RUR:SEX + INS:AGE + INS:SEX + VIS:AGE + } \\
\text { VIS:SEX + AGE:SEX }\end{array}$ & 5405.8 \\
\hline 'Forest' $~$ GPE + RUR + INS + VIS + AGE + SEX + RUR:SEX + INS:AGE + VIS:AGE & 5400.9 \\
\hline $\begin{array}{l}\text { ‘Park' GPE + RUR + INS + VIS + AGE + SEX + RUR:INS + RUR:VIS + RUR:AGE + RUR:SEX + } \\
\text { INS:VIS + INS:AGE + INS:SEX + VIS:AGE + VIS:SEX + AGE:SEX }\end{array}$ & 4158.4 \\
\hline 'Park' GPE + RUR + INS + VIS + AGE + SEX & 4200.5 \\
\hline $\begin{array}{l}\text { 'Park' GPE + RUR + INS + VIS + AGE + SEX + RUR:VIS + RUR:AGE + RUR:SEX + INS:AGE + } \\
\text { INS:SEX + VIS:SEX + AGE:SEX }\end{array}$ & 4154.7 \\
\hline 'Park' GPE + RUR + INS + VIS + AGE + SEX + RUR:VIS + RUR:AGE + VIS:SEX & 4149.6 \\
\hline 'Park' GPE + RUR + INS + AGE + SEX + RUR:VIS + RUR:AGE + VIS:SEX & 4148.1 \\
\hline \multicolumn{2}{|l|}{ Determinants of place specificity } \\
\hline PSP GPE + INS + RUR + VIS + AGE + SEX & 8902.61 \\
\hline $\begin{array}{l}\text { PSP GPE + INS + RUR + VIS + AGE + SEX + INS:RUR + INS:VIS + INS:AGE + INS:SEX + } \\
\text { RUR:VIS + RUR:AGE + RUR:SEX + VIS:AGE + VIS:SEX + AGE:SEX }\end{array}$ & 8902.86 \\
\hline $\mathrm{PSP} \sim \mathrm{GPE}+\mathrm{INS}+\mathrm{RUR}+\mathrm{VIS}+\mathrm{AGE}$ & 8901.67 \\
\hline
\end{tabular}

To cite this manuscript: Colléony A., Prévot A-C., Saint-Jalme M. \& Clayton S. (2017) What kind of landscape management can counteract the extinction of experience? Landscape and Urban Planning. 159: 23-31. 


\subsubsection{Determinant of place specificity}

Based on the best model in the ordinal regression (see Table 3), respondents who spent their childhood in a rural place and those who feel more connected to nature were more likely to mention a low level of place specificity, or in other words, very general, unspecified natural places (i.e. level 0 of place specificity; negative effects of RUR: $\beta=-$ $0.121, S E=0.032, \mathrm{p}<0.001$; negative effect of INS: $\beta=-0.088, S E=0.031, \mathrm{p}=0.005)$. At the opposite, the frequency of visit to natural places was positively associated with scores of place specificity (positive effect of VIS: $\beta=0.320, S E=0.033, \mathrm{p}<0.001$ ), suggesting that those who mention very frequent visits to natural places were more likely to mention specific (level 1 of PSP) or owned natural places (level 2 of PSP). As we found in the descriptive analysis, place specificity significantly differed between surveyed groups. Place specificity did not differ between men and women (SEX: $\beta=0.071$, $S E=0.069, \mathrm{p}=0.304)$.

\section{Discussion}

Our results add some key features to understand what landscapes are considered as natural places and are visited most often, as well as to propose some indications to help increase opportunities and orientations to go to nature and decrease the extinction of experience (Soga \& Gaston, 2016).

\subsection{Perception and determinants of natural areas}

Our results revealed a high diversity of places cited as "natural" by a large sampling of French adult population: more than 600 different places were cited, including forested, agricultural, urban or coastal areas, but also more recreational areas such as zoos or golf courses. Would this diversity correspond to so-called "natural places" according to ecology? Among the recent ecological classifications of land occupancy (including both natural and non natural areas), the European Corine Land Cover (CLC) (IGN, 2012a) has been extensively used by ecologists. The five main levels of the CLC classification are (1) artificial surfaces, (2) agricultural areas, (3) forest and semi natural areas, (4) wetlands and (5) water bodies. Indeed, many quoted places from our survey could be classified into one out of the five categories of the CLC; however, numerous other quotations of so-called natural places did not correspond to this typology. For instance, 
the quoted "Vincennes' Wood", a public park located in Paris, France, is roughly composed of a strongly managed open field with a lake, and a less managed forest. When a respondent indicated "Vincennes' wood", he did not specify whether he meant the more artificial part of the place, or the forested one. Similarly, many people mentioned visiting the "countryside", a place which could hardly be classified with the CLC; although some people may refer to the agricultural lands, other could refer to forested and semi natural areas.

Our results can be discussed together with a recent survey in Austria (Voigt \& Wurster, 2014): when visitors to a specific natural place were asked to cite the landscape structures that attracted their attention (open question) they mentioned almost all the categories of biotope that correspond to scientific ecological definition, even if their answers mostly did not fit exactly into the biotope classification. Consistently, when asking globally which natural areas people mostly visit (i.e. our study), a wide range of responses did not fit with ecological classification of natural areas. On the contrary, people can consider as "natural" some places that are not ecologically valued as natural by conservationists. This suggests that, in addition to their ecological value (for instance in terms of biodiversity), some places should be valued in terms of nature experiences and reconnection potential of individuals with nature, thereby having an indirect effect on conservation. Such varying points of views have also been observed between different stakeholders, for instance between farming and non-farming landowners in modeling scenarios for implementing sustainable landscapes (Southern, Lovett, O'Riordan, \& Watkinson, 2011). This thus highlights the importance of considering perceptions of various stakeholders, and in our case, the lay public's perception of natural areas, for landscape management strategies focused on providing green spaces where people live and work.

Besides the large variety of natural places listed, our second result is the high congruency of most of the respondents regarding few of those places, regardless of the surveyed groups: over the 600 different places cited, the five mentioned most often quoted represented $54 \%$ of the total. The most often quoted place was forest. This result is not surprising since one-third of French territory (16.3 million ha) is covered by 
forests (IGN, 2012b), a higher proportion than any other landscape use except agriculture. The fact that forests have been cited more often that countryside could be explained by limited public accessibility to agricultural fields in France, compared to forests, which are mostly owned by the State and opened to the public. However, the predominance of forests also suggests a very large appeal for forests, consistent with a large survey conducted almost 20 years ago on French respondents, which indicated that French forests are visited each year by the majority of the population (Dufour \& Loisel, 1996). This appeal may be explained by psychological reasons. Indeed, various studies revealed the high psychological restorative power of forest areas compared to urban ones (Park, Tsunetsugu, Kasetani, Kagawa, \& Miyazaki, 2010; Roe, Aspinall, \& Thompson, 2009). A recent study focusing on urban environments confirmed the recovery power of trees: it showed that a greater tree coverage in urban streets improved the recovery from a stressful experience (Jiang, Li, Larsen, \& Sullivan, 2014). Complementarily, forests, even highly managed by humans, still represent "nature, which is supposed to be largely free from human activities or left in its original state (...) and a region of wilderness which seems to be different from the intensively used urban area" (Schmithüsen \& Wild-Eck, 2000). Indeed, $70 \%$ of the French population believed more than twenty years ago that forests have to be protected in order to maintain the natural ecosystems (Dufour \& Loisel, 1996).

The second mostly frequently listed "natural place" was "parks". In France, "park" usually refers to urban parks in people's mind. Most cities worldwide display urban parks of various sizes, compositions and management practices. Although urbanization negatively affects biodiversity (McKinney, 2002), a recent study showed that even small urban greenspaces can harbor great levels of biodiversity, and that management practices could play an important role in enhancing plant and animal diversities (Shwartz, Muratet, Simon, \& Julliard, 2013). Moreover, in addition to the direct benefits they provide to people, such as recreation, well-being or restoration (Chiesura, 2004), urban parks can help mitigate the effects of climate change (Pickett et al., 2011), provide wildlife habitat and preserve biodiversity (Kowarik, 2011). Here, we showed that these parks are indeed 
considered as natural by people. They could therefore help reconnecting people to nature, as proposed by Miller and Hobbs (Miller \& Hobbs, 2002).

Respondents who spent their childhood in a rural environment and those who feel more connected with nature were more likely to mention forests. At the opposite, respondents who spent their childhood in more urbanized areas and those with a lower connectedness with nature were more likely to mention the "park" response. These opposite effects of rurality of place of childhood and connectedness with nature on the propensity of "forest" and "park" responses are striking. Because in France "park" usually refers to urban parks in people's mind, these results strongly suggest that the rurality level of place of childhood and connectedness with nature have determinants effects on the propensity of visits to either a forested or a more urbanized area. Although it remains unsure whether accessibility could prevent urban dwellers from visiting a forest for instance, recent research has shown that many people do not use green spaces they have access to, and authors suggested that orientations were stronger determinants of people's motivations to visit a park, compared to opportunities (Lin et al., 2014). Our results suggest that childhood experiences could partly determine the propensity to consider as natural and visit some specific places.

\subsection{Strong effect of childhood experiences of nature}

Our results also revealed that the frequency of visit to natural places at adulthood was strongly related to connectedness with nature and childhood experiences of nature. They are consistent with different recent results on the relations between childhood and adult behaviors: Gifford and Nilsson (Gifford \& Nilsson, 2014) suggested that people in rural areas tend to have more contact with nature than those in urban ones; Thompson et al. (Thompson, Aspinall, \& Montarzino, 2008) found that people who had frequent visits of natural place during childhood were more prepared to visit woodlands or green spaces alone as an adult. More generally, a growing consensus says that individual environmental identity is built during childhood (Chawla, 1988), and that nature experiences during childhood affects adult's pro-environmental behaviors (Hinds \& Sparks, 2008; Wells \& Lekies, 2006). 
More innovatively, we found that the connectedness with nature and childhood experiences of nature also influenced the score of place specificity, which we believe is a derived measure of the degree to which a person is tied to the place he/she visits. In the literature, place attachment and connectedness with nature have been mostly explored separately, assuming that connectedness with nature is a measure of the attachment to natural places (Gosling \& Williams, 2010). In our study, the score of place specificity was negatively correlated with connectedness with nature, stating that people who feel more connected to nature are less likely to specify particular places. We therefore suggest that a high sense of connection to nature could be detached from any specific place, with people appreciating and being comfortable in any kind of natural place. Finally, we suggest that the positive link we found between age and score of place specificity might be due to a greater access to a personal garden and stronger habits when becoming older. Indeed, settling in a place and residing there for many years could provide this place meanings associated with several life stages, such as marrying, having children and getting old: this results in "a rich network of place-related meanings, and offers a deep sense of self-continuity, something that more mobile people do not experience" (Lewicka, 2011). Although there might be a group of people who are more likely to have an "owned place", and thus a high score of place specificity, even people who own a place do not necessarily use it (e.g. for the "zoo" group, 180 respondents reported owning a garden, but only 10 of them mentioned their garden as the natural place they visit mostly). In contrast, some people personalized a place even when they do not own it (e.g. but saying "ours: park and forest", "the forest right next to my place" or "my parents' place").

\subsection{Management implications}

There is a growing consensus that we need to provide green spaces near to where people live and work, especially because exposure to nature tends to be positively related to the amount of neighborhood available urban green (Soga et al., 2015). Our results on the strong effect of childhood experiences of nature on frequency of visit, type of and place specificity of natural places underline the importance of also providing green spaces where young people live, as well as motivating parents to bring their children to these places, and/or implementing nature-based educational programs at school To cite this manuscript: Colléony A., Prévot A-C., Saint-Jalme M. \& Clayton S. (2017) What kind of landscape management can counteract the extinction of experience? Landscape and Urban Planning. 159: 23-31. 
(Lindemann-Matthies, 2006). Providing children more opportunities to experience nature will also provide them opportunities to reinforce their emotional ties with nature, and thus increase their nature orientation during adulthood. This is particularly important in the context of environmental inequities, especially in the cities where green is often unevenly distributed within cities, with reduced levels of vegetation for low-income, minority or other populations (Landry \& Chakraborty, 2009; Pham, Apparicio, Séguin, Landry, \& Gagnon, 2012). This reduces opportunities for city dwellers to experience nature. However, orientations to go to urban green spaces are also of concern: indeed, despite existing cultural differences in landscape preferences and nature uses (Buijs, Elands, \& Langers, 2009), public policies sometimes also perpetuate the social exclusion of some minorities from green spaces they have access to. For instance, Byrne (Byrne, 2012) observed that although Latinos are the numerically dominant ethno-racial group in Los Angeles, a relatively low proportion of them use a urban national park they have access to; further research then suggested that Latinos actually face ethno-racial and nativist barriers in accessing and using parks in the city, because of cultural histories of park-making and land-use systems (Byrne, 2012). Landscape managers should therefore also consider providing green spaces access equally, to reduce environmental inequity.

\subsection{Study limitations}

Our study suffers from some limitations, and any generalization to the French population must be done carefully. Notably, our sample was not random, because we surveyed people in five very different contexts. However, the complexity of the human society and individuals makes the selection of any representative sampling almost impossible for psychological surveys (Gobo, 2006). So far, most psychological studies relied on specific groups of respondents, mostly university students, and can hardly be transferred to a more general audience. In the same way, our sample is not representative of the French population. However, we deliberately merged different sampled groups to increase the sample size, and to better approach representativeness of the French population. The strong consistency we found between the most quoted natural places among the five surveyed groups gives subsequent support to our strategy and strengthens our findings. In that sense, we are confident that our methodological strategy led to generalizable results, in the French cultural context. However, further research is needed to explore cultural To cite this manuscript: Colléony A., Prévot A-C., Saint-Jalme M. \& Clayton S. (2017) What kind of landscape management can counteract the extinction of experience? Landscape and Urban Planning. 159: 23-31. 
differences in perception of natural places. It would not be surprising if, for example, North American respondents name different types of natural places, reflecting the differences in landscapes between United States and France. Finally, it would be interesting to explore whether people primarily visit natural places because of their accessibility, or because they appreciate those specific places.

\section{Conclusions}

To conclude, this study showed that, even if visited natural places are very diverse, there seems to be a common attraction to a few of these places, especially forests, which cover a large proportion of the French landscape. The degree to which people have experienced nature during childhood is a key determinant of whether they mostly visit forested or more urbanized areas at adulthood. This childhood experience of nature was also found to influence the frequency of visits of natural places during adulthood. Therefore, we suggest that nature experience during childhood is crucial to determine the likelihood of natural place visits during adulthood, but more importantly to determine the type of nature experience people could be looking for, either in forested or more urbanized natural areas. Finally, we found that the more people felt connected to nature, the less they needed to refer to a specific natural place, in other words that a high sense of connection to nature could lead to an appreciation of nature that is detached from any particular natural place. This study has implications regarding the extinction of nature experience. We encourage environmental educators to diversify as much as possible the natural places they use for their activities, to show participants that one activity does not belong to one specific natural place, and thus to encourage people to visit various places. We also encourage landscape managers to consider equally increasing for the population

the accessibility and attractiveness of some natural places for recreational and restorative activities, in order to increase people's orientations toward nature, from a young age.

\section{Supporting Information}

The ranks of the quoted natural areas for each surveyed group (Appendix A) are available online. The authors are solely responsible for the content and functionality of these materials. Queries (other than absence of the material) should be directed to the corresponding author.

To cite this manuscript: Colléony A., Prévot A-C., Saint-Jalme M. \& Clayton S. (2017) What kind of landscape management can counteract the extinction of experience? Landscape and Urban Planning. 159: 23-31. 


\section{Acknowledgements}

We wish to thank R. Mathevet and M.-X. Truong for allowing us to use some of the data they collected, but not analyzed. We also thank S. Ferreira, the director of the Zoological Park of Paris, and R. Simon, the director of the Reserve de la Haute-Touche, for allowing us to collect data within their zoos. Finally, we thank the two anonymous reviewers for providing feedback that greatly improved this manuscript.

\section{References}

Anton, C. E., \& Lawrence, C. (2014). Home is where the heart is: The effect of place of residence on place attachment and community participation. Journal of Environmental Psychology, 40, 451-461. http://doi.org/10.1016/j.jenvp.2014.10.007

Aron, A., Aron, E. N., \& Smollan, D. (1992). Inclusion of Other in the Self Scale and the structure of interpersonal closeness. Journal of Personality and Social Psychology, 63(4), 596-612. http://doi.org/10.1037/0022-3514.63.4.596

Bixler, R. D., Floyd, M. F., \& Hammitt, W. E. (2002). Environmental socialization quantitative tests of the childhood play hypothesis. Environment and Behavior, 34(6), 795-818. http://doi.org/10.1177/001391602237248

Bratman, G. N., Hamilton, J. P., \& Daily, G. C. (2012). The impacts of nature experience on human cognitive function and mental health. Annals of the New York Academy of Sciences, 1249, 118-136. http://doi.org/10.1111/j.1749-6632.2011.06400.x

Bratman, G. N., Hamilton, J. P., Hahn, K. S., Daily, G. C., \& Gross, J. J. (2015). Nature experience reduces rumination and subgenual prefrontal cortex activation. Proceedings of the National Academy of Sciences, 112(28), 8567-8572.

Buijs, A. E., Elands, B. H. M., \& Langers, F. (2009). No wilderness for immigrants: Cultural differences in images of nature and landscape preferences. Landscape and Urban Planning, 91(3), 113-123. http://doi.org/10.1016/j.landurbplan.2008.12.003

Buijs, A. E., Hovardas, T., Figari, H., Castro, P., Devine-Wright, P., Fischer, A., ... Selge, S. (2012). Understanding people's ideas on natural resource management : research on social representations of nature. Society \& Natural Resources, 25(11), 1167.

Byrne, J. (2012). When green is White: The cultural politics of race, nature and social exclusion in a Los Angeles urban national park. Geoforum, 43(3), 595-611. http://doi.org/10.1016/j.geoforum.2011.10.002

Chawla, L. (1988). Children's concern for the natural environment. Children's Environments Quarterly, 5(3), 13-20.

Chiesura, A. (2004). The role of urban parks for the sustainable city. Landscape and Urban Planning, 68(1), 129-138. http://doi.org/10.1016/j.landurbplan.2003.08.003

Clayton, S. (2012). Environment and identity. In Oxford Handbook of Environmental and Conservation Psychology (Owford University Press, pp. 164-180). New York: S. Clayton.

Clayton, S., Fraser, J., \& Saunders, C. D. (2009). Zoo experiences: conversations, connections, and concern for animals. Zoo Biology, 28(5), 377-397. http://doi.org/10.1002/zoo.20186

To cite this manuscript: Colléony A., Prévot A-C., Saint-Jalme M. \& Clayton S. (2017) What kind of landscape management can counteract the extinction of experience? Landscape and Urban Planning. 159: 23-31. 
Dufour, A., \& Loisel, J.-P. (1996). Les opinions des Français sur l'environnement et la forêt (Collection des Rapports No. R174) (p. 150p). CREDOC.

Fox, J., \& Weisberg, S. (2016). Package "car": Companion to Applied Regression (Version 2.1 2).

Gifford, R., \& Nilsson, A. (2014). Personal and social factors that influence pro-environmental concern and behaviour: A review. International Journal of Psychology, 49(3), 141-157. http://doi.org/10.1002/ijop.12034

Gobo, G. (2006). Sampling, representativeness and generalizability. In Qualitative Research Practice (SAGE, p. 552). Clive Seale, David Silverman, Jaber F. Gubrium and Giampietro Gobo.

Gosling, E., \& Williams, K. J. H. (2010). Connectedness to nature, place attachment and conservation behaviour: Testing connectedness theory among farmers. Journal of Environmental Psychology, 30(3), 298-304. http://doi.org/10.1016/j.jenvp.2010.01.005

Han, K.-T. (2007). Responses to Six Major Terrestrial Biomes in Terms of Scenic Beauty, Preference, and Restorativeness. Environment and Behavior, 39(4), 529-556. http://doi.org/10.1177/0013916506292016

Haubo, R. (2015). Package “ordinal”: Regression Models for Ordinal Data.

Hinds, J., \& Sparks, P. (2008). Engaging with the natural environment: The role of affective connection and identity. Journal of Environmental Psychology, 28(2), 109-120. http://doi.org/10.1016/j.jenvp.2007.11.001

IGN. (2012a). Corine Land Cover 2006.

IGN. (2012b). La forêt en chiffres et en cartes (p. 28p). Institut National de l'Information Géographique et Forestière.

Jiang, B., Li, D., Larsen, L., \& Sullivan, W. C. (2014). A Dose-Response Curve Describing the Relationship Between Urban Tree Cover Density and Self-Reported Stress Recovery. Environment and Behavior, 13916514552321. http://doi.org/10.1177/0013916514552321

Kaplan, R., \& Kaplan, S. (1989). The Experience of Nature: A Psychological Perspective. New York, NY, US: Cambridge University Press.

Kowarik, I. (2011). Novel urban ecosystems, biodiversity, and conservation. Environmental Pollution, 159(8-9), 1974-1983. http://doi.org/10.1016/j.envpol.2011.02.022

Landry, S. M., \& Chakraborty, J. (2009). Street Trees and Equity: Evaluating the Spatial Distribution of an Urban Amenity. Environment and Planning A, 41(11), 2651-2670. http://doi.org/10.1068/a41236

Lewicka, M. (2011). Place attachment: How far have we come in the last 40 years? Journal of Environmental Psychology, 31(3), 207-230. http://doi.org/10.1016/j.jenvp.2010.10.001

Lin, B. B., Fuller, R. A., Bush, R., Gaston, K. J., \& Shanahan, D. F. (2014). Opportunity or Orientation? Who Uses Urban Parks and Why. PLOS ONE, 9(1), e87422. http://doi.org/10.1371/journal.pone.0087422

Lindemann-Matthies, P. (2006). Investigating Nature on the Way to School: Responses to an educational programme by teachers and their pupils. International Journal of Science Education, 28(8), 895-918. http://doi.org/10.1080/10670560500438396

McKinney, M. L. (2002). Urbanization, Biodiversity, and Conservation. BioScience, 52(10), 883-890.

Miller, J. R. (2005). Biodiversity conservation and the extinction of experience. Trends in Ecology \& Evolution, 20(8), 430-434. http://doi.org/10.1016/j.tree.2005.05.013

To cite this manuscript: Colléony A., Prévot A-C., Saint-Jalme M. \& Clayton S. (2017) What kind of landscape management can counteract the extinction of experience? Landscape and Urban Planning. 159: 23-31. 
Miller, J. R., \& Hobbs, R. J. (2002). Conservation where people live and work. Conservation Biology, 16(2), 330-337. http://doi.org/10.1046/j.1523-1739.2002.00420.x

Mitchell, R., \& Popham, F. (2008). Effect of exposure to natural environment on health inequalities: an observational population study. The Lancet, 372(9650), 1655-1660. http://doi.org/10.1016/S0140-6736(08)61689-X

Nisbet, E. K., Zelenski, J. M., \& Murphy, S. A. (2009). The Nature Relatedness Scale: Linking Individuals' Connection With Nature to Environmental Concern and Behavior. Environment and Behavior, 41(5), 715-740. http://doi.org/10.1177/0013916508318748

Park, B. J., Tsunetsugu, Y., Kasetani, T., Kagawa, T., \& Miyazaki, Y. (2010). The physiological effects of Shinrin-yoku (taking in the forest atmosphere or forest bathing): evidence from field experiments in 24 forests across Japan. Environmental Health and Preventive Medicine, 15(1), 18-26. http://doi.org/10.1007/s12199-009-0086-9

Pham, T.-T.-H., Apparicio, P., Séguin, A.-M., Landry, S., \& Gagnon, M. (2012). Spatial distribution of vegetation in Montreal: An uneven distribution or environmental inequity? Landscape and Urban Planning, 107(3), 214-224. http://doi.org/10.1016/j.landurbplan.2012.06.002

Pickett, S. T. A., Cadenasso, M. L., Grove, J. M., Boone, C. G., Groffman, P. M., Irwin, E., ... Warren, P. (2011). Urban ecological systems: Scientific foundations and a decade of progress. Journal of Environmental Management, 92(3), 331-362. http://doi.org/10.1016/j.jenvman.2010.08.022

Pyle, R. M. (1978). The extinction of experience. Horticulture, (56), 64-67.

$\mathrm{R}$ Core Team. (2013). R: A language and Environment for Statistical Computing. Vienna, Austria: R Foundation for Statistical Computing.

Roe, J., Aspinall, P., \& Thompson, C. W. (2009). Forest school: evidence for restorative health benefits in young people (Access \& Health). Forestry Commission Scotland.

Sandifer, P. A., Sutton-Grier, A. E., \& Ward, B. P. (2015). Exploring connections among nature, biodiversity, ecosystem services, and human health and well-being: Opportunities to enhance health and biodiversity conservation. Ecosystem Services, 12, 1-15. http://doi.org/10.1016/j.ecoser.2014.12.007

Schmithüsen, F., \& Wild-Eck, S. (2000). Uses and perceptions of forests by people living in urban areas-findings from selected empirical studies. Forstwissenschaftliches Centralblatt Vereinigt Mit Tharandter Forstliches Jahrbuch, 119(1-6), 395-408.

Schultz, P. W. (2000). Empathizing With Nature: The Effects of Perspective Taking on Concern for Environmental Issues. Journal of Social Issues, 56(3), 391-406.

Schultz, P. W. (2001). The Structure Of Environmental Concern: Concern For Self, Other People, And The Biosphere. Journal of Environmental Psychology, 21(4), 327-339. http://doi.org/10.1006/jevp.2001.0227

Shwartz, A., Muratet, A., Simon, L., \& Julliard, R. (2013). Local and management variables outweigh landscape effects in enhancing the diversity of different taxa in a big metropolis. Biological Conservation, 157, 285-292. http://doi.org/10.1016/j.biocon.2012.09.009

Soga, M., \& Gaston, K. J. (2016). Extinction of experience: the loss of human-nature interactions. Frontiers in Ecology and the Environment, 14(2), 94-101. http://doi.org/10.1002/fee.1225

Soga, M., Yamaura, Y., Aikoh, T., Shoji, Y., Kubo, T., \& Gaston, K. J. (2015). Reducing the extinction of experience: Association between urban form and recreational use of public

To cite this manuscript: Colléony A., Prévot A-C., Saint-Jalme M. \& Clayton S. (2017) What kind of landscape management can counteract the extinction of experience? Landscape and Urban Planning. 159: 23-31. 
greenspace. Landscape and Urban Planning, 143, 69-75. http://doi.org/10.1016/j.landurbplan.2015.06.003

Southern, A., Lovett, A., O'Riordan, T., \& Watkinson, A. (2011). Sustainable landscape governance: Lessons from a catchment based study in whole landscape design. Landscape and Urban Planning, 101(2), 179-189. http://doi.org/10.1016/j.landurbplan.2011.02.010

Thompson, C. W., Aspinall, P., \& Montarzino, A. (2008). The Childhood Factor Adult Visits to Green Places and the Significance of Childhood Experience. Environment and Behavior, 40(1), 111-143. http://doi.org/10.1177/0013916507300119

Voigt, A., \& Wurster, D. (2014). Does diversity matter? The experience of urban nature's diversity: Case study and cultural concept. Ecosystem Services. http://doi.org/10.1016/j.ecoser.2014.12.005

Wells, N. M., \& Lekies, K. S. (2006). Nature and the Life Course: Pathways from Childhood Nature Experiences to Adult Environmentalism. Children, Youth and Environments, 16(1), 1-24. 
Appendix A: Ranks of quoted places mentioned by at least 10 respondents, for each group. Numbers of quotes are in italics between brackets (e.g. "forest" is the most cited place for students, followed by "park", and so on). Quoted places are translated from French quotes (in italics in brackets).

\begin{tabular}{|l|c|c|c|c|c|}
\hline $\begin{array}{l}\text { Natural places (French } \\
\text { quotes) }\end{array}$ & Student & Adopter & Web & WoW & Zoo \\
\hline Forest (forêt) & $1(433)$ & $1(664)$ & $1(109)$ & $1(292)$ & $1(121)$ \\
\hline Park (parc) & $2(150)$ & $2(496)$ & $4(26)$ & $2(223)$ & $3(78)$ \\
\hline Countryside (campagne) & $5(111)$ & $3(344)$ & $5(23)$ & $5(65)$ & $2(87)$ \\
\hline Mountain (montagne) & $4(135)$ & $4(305)$ & $8(10)$ & $6(45)$ & $6(17)$ \\
\hline Garden (jardin) & $6(57)$ & $6(207)$ & $2(28)$ & $3(153)$ & $7(15)$ \\
\hline Sea (mer) & $3(139)$ & $5(241)$ & $(8)$ & $16(14)$ & $8(13)$ \\
\hline Woodland (bois) & $8(24)$ & $7(179)$ & $6(11)$ & $8(44)$ & $4(23)$ \\
\hline Beach (plage) & $7(47)$ & $12(75)$ & $(8)$ & $10(36)$ & $(5)$ \\
\hline Zoo (zoo) & $(4)$ & $8(139)$ & $(2)$ & $(7)$ & $10(10)$ \\
\hline $\begin{array}{l}\text { Public garden (jardin } \\
\text { public) }\end{array}$ & $(9)$ & $10(84)$ & $(6)$ & $11(25)$ & $5(23)$ \\
\hline Fields (champs) & $11(17)$ & $15(31)$ & $(9)$ & $4(68)$ & $(7)$ \\
\hline $\begin{array}{l}\text { Vincennes' wood (bois de } \\
\text { Vincennes) }\end{array}$ & $(5)$ & $9(87)$ & $(3)$ & $(8)$ & $9(11)$ \\
\hline Sea side (bord de mer) & $(6)$ & $11(84)$ & $(6)$ & $(5)$ & $(6)$ \\
\hline Lake (lac) & $15(10)$ & $13(40)$ & $(3)$ & $12(24)$ & $(6)$ \\
\hline River (rivière) & $10(18)$ & $18(17)$ & $(2)$ & $13(18)$ & $(1)$ \\
\hline Urban park (parc urbain) & $(2)$ & $(8)$ & $3(27)$ & $(3)$ & $11(10)$ \\
\hline
\end{tabular}

